PRACE NAUKOWE UNIWERSYTETU EKONOMICZNEGO WE WROCLAWIU

\title{
Kinga Bauer
}

Uniwersytet Ekonomiczny w Krakowie

e-mail: bauerk@uek.krakow.pl

\section{Malgorzata Macuda}

Uniwersytet Ekonomiczny w Poznaniu

e-mail: malgorzata.macuda@ue.poznan.pl

\section{SPRAWOZDANIE FINANSOWE JAKO ŹRÓDLO INFORMACJI DLA INTERESARIUSZY RESTRUKTURYZOWANEGO SZPITALA}

\section{FINANCIAL STATEMENT AS A SOURCE OF INFORMATION FOR STAKEHOLDERS OF THE RESTRUCTURED HOSPITAL}

DOI: $10.15611 /$ pn.2018.503.03

JEL Classification: M41, H83, G34

Streszczenie: Sprawozdanie finansowe jest najważniejszym źródłem informacji o kondycji finansowej jednostki. Może być ono również przydane dla interesariuszy restrukturyzowanych szpitali. Celem artykułu była analiza i ocena praktyk związanych z wykorzystaniem informacyjnej roli sprawozdan finansowych w procesach restrukturyzacyjnych jednostek sektora opieki zdrowotnej. Na metodę badawczą złożyły się studia literaturowe, analizy przypadków - powszechnie dostępnych (on-line) planów restrukturyzacji szpitali oraz wnioskowanie logiczne. W wyniku przeprowadzonych badań stwierdzono, iż zauważalne jest zróżnicowane podejście do udostępniania informacji finansowych w planach restrukturyzacji szpitali. Badane jednostki chętniej udostępniają obliczone wskaźniki finansowe oraz sprawozdania finansowe prognozowane dla okresów przyszłych niż sporządzone na podstawie danych historycznych.

Słowa kluczowe: szpital, restrukturyzacja, sprawozdanie finansowe, interesariusze.

Summary: Financial statement is the most important source of information about the condition of an entity. It may also be useful to the stakeholders of restructured hospitals. The purpose of this article was to analyze and evaluate practices related to the use of the informative role of financial statements in the restructuring processes of healthcare entities. The research method consisted of literature studies, logical inference and case studies - commonly available (on-line) restructuring plans for hospitals. As a result of the studies, a differentiated approach to financial data disclosure in hospital restructuring plans was observed. The entities studied are more willing to share calculated financial ratios and forecasted financial statements for future periods than those based on historical data. The main conclusion, however, is that hospitals being restructured are generally reluctant to make available any restructuring plans and financial statements.

Keywords: hospital, restructuring, financial statement, stakeholders. 


\section{Wstęp}

Szpitale jako samodzielne jednostki sektora opieki zdrowotnej są z założenia jednostkami samofinansującymi, na których spoczywa odpowiedzialność za zarządzanie wszystkimi aspektami związanymi z ich działalnością [Wawrowski 2014, s. 393]. Stanowią specyficzny podmiot gospodarczy, gdyż ich priorytetem nie jest osiaganie, a tym bardziej maksymalizowanie zysku. Cechują się stałą gotowością do udzielania świadczeń zdrowotnych, których odmienny charakter powoduje niemożność stosowania klasycznych reguł rynkowych [Macuda 2016, s. 403]. Szpitalom przyświeca cel społeczny. Ich działalność z założenia ma być skoncentrowana na świadczeniu wysokiej jakości usług medycznych służących ratowaniu zdrowia i życia pacjentów. Równocześnie jednostki te, aby prawidłowo funkcjonować, potrzebują przychodów dla pokrycia kosztów działalności oraz sfinansowania rozwoju [Zaleska, Wallis 2008, s. 218]. Uzyskiwanie nadwyżki (zysku) umożliwia odtwarzanie i rozszerzanie bazy specjalistycznego sprzętu i aparatury medycznej niezbędnych przy stosowaniu nowoczesnych technik leczenia [Chluska 2005, s. 127].

W związku z pojawiającymi się w praktyce przypadkami niedoborów środków finansowych szpitale narażone są na trudności finansowe, które mogą prowadzić do ich likwidacji. Trudności finansowe nie zawsze muszą jednak prowadzić do ostatecznych rozwiązań. W krajach takich jak Polska, gdzie dominuje publiczny sektor opieki zdrowotnej, problemy finansowe szpitali rozwiązywane są często przez wsparcie finansowe, głównie ze strony samorządów lokalnych [Bem i in. 2014]. Zjawiskiem, które także występuje w praktyce zadłużonych szpitali, są procesy restrukturyzacyjne [por. m.in. Chluska 2010; Węgrzyn 2013; Klich 2013; Sagan, Sobczak 2014].

Z punktu widzenia prawa rok 2016 przyniósł w Polsce nowe rozwiązania w tym zakresie, dopuszczając możliwość przeprowadzenia postępowania restrukturyzacyjnego. 1 stycznia 2016 r. weszło w życie nowe Prawo restrukturyzacyjne [Ustawa z 15 maja 2015], zgodnie z którym wszystkie podmioty utworzone na mocy ustawy z dnia 15 kwietnia 2011 r. o działalności leczniczej mogą regulować swoje zobowiązania $\mathrm{W}$ trybie sądowego postępowania restrukturyzacyjnego [Zimmerman 2016].

Restrukturyzacja szpitali nie powinna być tylko procedurą prawna, lecz przede wszystkim procesem ekonomicznym, którego powodzenie może zależeć od rzetelnej informacji finansowej. Główną rolę w jej dostarczaniu odgrywa rachunkowość. Spełnia ona funkcję informacyjną zarówno dla kierownictwa jednostki, jak i użytkowników zewnętrznych [Hass-Symotiuk (red.) 2010]. Sprawozdanie finansowe będące produktem finalnym rachunkowości nie jest w pełni dostosowane do spełnienia potrzeb informacyjnych interesariuszy restrukturyzowanych szpitali, gdyż nie przedstawia skutków zdarzeń nietypowych. Jednak uzupełnione o część opisową zawartą w informacji dodatkowej może dać podstawę do oceny kondycji finansowej i możliwości rozwoju restrukturyzowanej jednostki sektora opieki zdrowotnej [Chluska 2010]. 
W kontekście powyższych rozważań celem artykułu jest analiza i ocena praktyk związanych z wykorzystaniem informacyjnej roli sprawozdań finansowych w procesach restrukturyzacyjnych jednostek sektora opieki zdrowotnej. Na metodę badawczą składają się studia literaturowe, wnioskowanie logiczne oraz analizy przypadków - powszechnie dostępnych (on-line) planów restrukturyzacji szpitali.

\section{Sprawozdanie finansowe szpitala}

Głównym źródłem informacji o działalności każdej jednostki gospodarczej, również szpitala, w danym okresie jest sprawozdawczość, którą Hass-Symotiuk [2008, s. 657] określa mianem zestawień liczbowych sporządzanych okresowo lub jednorazowo dla różnych celów (wewnętrznych i zewnętrznych) przekazywanych w ustalonych terminach jednostkom uprawnionym do ich otrzymania. Wskazuje ona podział sprawozdawczości na rzeczową i finansową ze względu na źródła oraz charakter zawartych informacji. Sprawozdawczość finansową definiuje zaś jako usystematyzowany zbiór informacji o charakterze wartościowym pochodzących przede wszystkim z rachunkowości, w której odzwierciedlona została sytuacja majątkowa i finansowa oraz osiagnięte przez szpital rezultaty działalności, przypominając jednocześnie, iż forma oraz treść informacji zawartych w sprawozdawczości finansowej określone są przepisami prawa.

Sprawozdawczość nie może ująć wszystkich informacji, chociażby ze względu na swą ograniczoną pojemność. Dlatego trzeba dokonać wyboru odpowiednich informacji, pogrupować je w określone zbiory i podzbiory oraz uzupełnić te informacje o dane powstające poza rachunkowością, a stanowiące ich objaśnienia [Kołaczyk 1999, s. 460]. Sprawozdawczość to usystematyzowany zbiór wyselekcjonowanych i syntetycznych informacji o dominującym charakterze finansowym, tworzonych głównie przez rachunkowość i częściowo poza nią, odnoszących się do przeszłej i obecnej sytuacji finansowo-majątkowej jednostki gospodarczej oraz wyniku finansowego jako rezultatu jej działalności, pozwalających wyciagać wnioski dotyczące przyszłości [Samelak 2013, s. 79]. Ujęcie obok danych sprawozdawczych z bieżącego roku także danych porównawczych na dzień kończący poprzedni rok obrotowy zwiększa wartość poznawczą informacji zawartych w sprawozdaniach finansowych, umożliwia przeprowadzanie wnikliwej analizy, a w konsekwencji dokonywanie oceny całokształtu działalności jednostki gospodarczej oraz tendencji rozwojowych w niej zachodzących.

Szpitale przechodzące proces restrukturyzacji są z założenia jednostkami kontynuującymi działalność gospodarczą, co powoduje, iż ich sprawozdania finansowe nie różnią się od innych jednostek świadczących usługi zdrowotne [Chluska 2010]. Szpital sporządza sprawozdanie finansowe zgodnie z ustawą o rachunkowości. O uzyskanym wyniku finansowym decydują osiągnięte przychody, przy czym głównym źródłem ich pochodzenia jest sprzedaż świadczeń zdrowotnych oraz poniesione przy ich realizacji koszty. Jeżeli szpital zamierza zaprzestać określonego zakresu działalności (np. likwidacja oddziału szpitalnego), co wpłynie na przychody i koszty 
przyszłych okresów sprawozdawczych, to odpowiednie przychody i koszty z tym związane należy wykazać odrębnie od tych z działalności kontynuowanej [Hass-Symotiuk (red.) 2015, s. 334]. O wyborze wariantu rachunku zysków i strat, który warunkują stosowane w jednostce rozwiązania dotyczące rachunku kosztów, decyduje zarządzający szpitalem. Rachunek zysków i strat sporządzany jest najczęściej przez szpitale w wariancie porównawczym. Prezentacja kosztów według rodzaju uniemożliwia menedżerom zarząadzanie kosztami oraz ich kontrolę $\mathrm{w}$ związku $\mathrm{z}$ brakiem informacji o przyczynach ich powstawania, a także o ich wzroście lub spadku. Wystarczająca dla sporządzenia sprawozdania finansowego informacja o kosztach rzeczywistych nie jest $\mathrm{w}$ stanie zaspokoić potrzeb zarządzających szpitalem [Świderska, Pielaszek 2015, s. 60-72].

Wykorzystanie sprawozdania finansowego szpitala jako źródła informacji nie może ograniczać się wyłącznie do odczytania zawartych w nim wielkości będących agregatami danych. Jego ocena i interpretacja powinna prowadzić do wyjaśnienia przyczyn, ujawnienia zależności i sygnalizowania zagrożeń [Hass-Symotiuk (red.) 2010, s. 261].

$\mathrm{W}$ procesie restrukturyzacji cenne informacje mogą zostać ujęte $\mathrm{w}$ informacji dodatkowej, jednak również dane zawarte w częściach liczbowych sprawozdania finansowego mogą służyć sporządzeniu analiz finansowych mających na celu ocenę kondycji finansowej jednostki. Analiza finansowa restrukturyzowanego szpitala może zarówno stanowić system wczesnego ostrzegania, jak i - po zakończonej restrukturyzacji - wskazywać na słuszność podjętych działań [Chluska 2010].

\section{Potrzeby informacyjne interesariuszy restrukturyzowanego szpitala}

Wielowiekowa historia rachunkowości wskazuje, że jej rozwój był zawsze zdeterminowany zmieniającymi się oczekiwaniami informacyjnymi rozszerzającej się grupy interesariuszy, co świadczy o przydatności i użyteczności tej dyscypliny wiedzy teoretycznej i praktycznej. Jednym z podstawowych założeń rachunkowości, gwarantującym uniknięcie asymetrii informacyjnej, jest równe traktowanie, odnośnie do treści i dostępności, różnych odbiorców sprawozdawczości finansowej jednostki gospodarczej [Samelak 2013, s. 101-102]. Informacje zawarte w sprawozdaniach finansowych stanowią punkt wyjścia do oceny dokonań jednostki, również szpitala.

Zdaniem Samelaka [2004, s. 116-118; 2013, s. 110] trzeba zwrócić uwagę na fakt, iż sprawozdanie jest sporządzane przede wszystkim dla potrzeb interesariuszy zewnętrznych, odbiorcy wewnętrzni mają bowiem możliwość poznania obrazu sytuacji jednostki gospodarczej także z innych źródeł. Poszczególni użytkownicy rocznego sprawozdania finansowego reprezentują zróżnicowane potrzeby informacyjne i posługują się jego zawartością informacyjną dla różnych celów i różnych decyzji. Wydaje się, że najsilniejsze zainteresowanie informacjami pochodzącymi ze sprawozdania wykazują właściciele (organy założycielskie), gdyż chcą być informowani co najmniej okresowo o powodzeniu lub niepowodzeniu działalności gospodarczej. 
W jego opinii rachunkowość powinna pełnić rolę z jednej strony wiarygodnego i porównywalnego źródła informacji dla interesariuszy zewnętrznych, dostarczanych w formie okresowych sprawozdań finansowych, które umożliwiłyby określenie pozycji finansowej jednostki gospodarczej, z drugiej zaś rolę podsystemu informacyjnego systemu informacji ekonomicznej generującego informacje przydatne do wewnętrznej oceny jej dotychczasowej działalności oraz rzetelnego narzędzia wspomagającego proces decyzyjny zarządzających.

Jak podkreśla Chluska [2004, s. 555], rachunkowość w szpitalu jest przede wszystkim systemem informacyjnym, którego zasadniczym przeznaczeniem jest zaspokajanie potrzeb informacyjnych użytkowników zewnętrznych (tabela 1) i wewnętrznych (tabela 2). Uwzględniając taki podział odbiorców informacji, można wyróżnić zewnętrzną funkcję informacyjną (w ramach której rachunkowość dostarcza informacji różnym jednostkom z otoczenia, np. płatnikowi, kredytodawcom, kontrahentom, instytucjom rządowym itp.) oraz wewnętrzną funkcję informacyjną (pełnioną na potrzeby zarządzania szpitalem, przy czym informacje powinny być tak przetworzone, aby na ich podstawie zarządzający mogli podejmować uzasadnione decyzje).

Tabela 1. Potrzeby informacyjne interesariuszy wewnętrznych szpitala

\begin{tabular}{|c|c|}
\hline Interesariusze & Potrzeby informacyjne \\
\hline $\begin{array}{l}\text { Rada nadzorcza/ } \\
\text { Rada społeczna }\end{array}$ & $\begin{array}{l}\text { - wielkość przychodów ze sprzedaży świadczeń zdrowotnych } \\
\text { - wielkość kosztów ponoszonych w ramach działalności podstawowej } \\
\text { (realizacja świadczeń) } \\
\text { - wielkość wyniku finansowego } \\
\text { - stan zadłużenia szpitala } \\
\text { - kondycja finansowa szpitala }\end{array}$ \\
\hline $\begin{array}{l}\text { Kierownictwo szpitala } \\
\text { (wyższych i niższych } \\
\text { szczebli zarządzania } \\
\text { - zarząd, dyrekcja, } \\
\text { ordynatorzy oddziałów } \\
\text { szpitalnych, kierownicy } \\
\text { przychodni, poradni, } \\
\text { pracowni, laboratoriów } \\
\text { diagnostycznych, apteki, } \\
\text { prosektorium) }\end{array}$ & $\begin{array}{l}\text { - kontrola i analiza sytuacji majątkowo-finansowej szpitala } \\
\text { - wielkość przychodów ze sprzedaży świadczeń zdrowotnych } \\
\text { - wielkość kosztów ponoszonych w ramach działalności podstawowej } \\
\text { (realizacja świadczeń zdrowotnych) } \\
\text { - wielkość wyniku finansowego } \\
\text { - rentowność } \\
\text { - stan zadłużenia szpitala } \\
\text { - } \text { efynność finansowa } \\
\text { i osobowych } \\
\text { - ocena dokonań } \\
\text { - organizacja procesu świadczenia usług }\end{array}$ \\
\hline $\begin{array}{l}\text { Pracownicy } \\
\text { (personel medyczny, } \\
\text { inaczej zwany białym - } \\
\text { lekarze, pielęgniarki oraz } \\
\text { niemedyczny, głównie } \\
\text { administracyjny) }\end{array}$ & $\begin{array}{l}\text { - } \text { stabilność pracodawcy } \\
\text { - ocena zdolności szpitala do wypłacania wynagrodzeń } \\
\text { - możliwości tworzenia nowych miejsc pracy }\end{array}$ \\
\hline
\end{tabular}

Źródło: opracowanie własne na podstawie [Hass-Symotiuk (red.) 2010, s. 30-33; 2014, s. 26-31]. 
Tabela 2. Potrzeby informacyjne interesariuszy zewnętrznych szpitala

\begin{tabular}{|c|c|}
\hline Interesariusze & Potrzeby informacyjne \\
\hline $\begin{array}{l}\text { Organy założycielskie, } \\
\text { potencjalni inwestorzy }\end{array}$ & $\begin{array}{l}\text { - wartość majątku i efektywność jego wykorzystania } \\
\text { - } \text { sytuacja finansowa } \\
\text { - zdolność szpitala do generowania przychodów i dodatniego wyniku } \\
\text { finansowego (poziom przychodów, kosztów i wyniku finansowego) }\end{array}$ \\
\hline $\begin{array}{l}\text { Narodowy Fundusz Zdrowia } \\
\text { (płatnik) }\end{array}$ & $\begin{array}{l}\text { - } \text { podaż świadczeń zdrowotnych } \\
\text { - dostępność, kompleksowość i jakość świadczeń zdrowotnych } \\
\text { - koszty świadczeń zdrowotnych } \\
\text { - ceny świadczeń zdrowotnych } \\
\text { - gwarancja realizacji kontraktów }\end{array}$ \\
\hline Pacjenci & $\begin{array}{l}\text { - } \text { ceny świadczeń zdrowotnych } \\
\text { - lista oczekujących i czas oczekiwania na świadczenia zdrowotne } \\
\text { - rozmieszczenie terytorialne szpitali } \\
\text { - respektowanie praw pacjenta } \\
\text { - } \text { sytuacja finansowa szpitala }\end{array}$ \\
\hline $\begin{array}{l}\text { Instytucje rządowe } \\
\text { (Ministerstwo Zdrowia, Główny } \\
\text { Urząd Statystyczny, Urząd } \\
\text { Skarbowy) }\end{array}$ & $\begin{array}{l}\text { - alokacja zasobów } \\
\text { - struktura i kwalifikacje zatrudnionego personelu białego } \\
\text { - wielkość i struktura zrealizowanych świadczeń zdrowotnych } \\
\text { - poziom przychodów, kosztów i wyniku finansowego } \\
\text { - sytuacja finansowa } \\
\text { - stan zadłużenia szpitala }\end{array}$ \\
\hline Kredytodawcy, pożyczkodawcy & - zdolność do spłaty kredytu wraz z odsetkami \\
\hline $\begin{array}{l}\text { Kontrahenci (dostawcy aparatury } \\
\text { i sprzętu medycznego, leków, } \\
\text { materiałów medycznych i } \\
\text { niemedycznych, energii, usług) }\end{array}$ & $\begin{array}{l}\text { - zdolność do spłaty zobowiązań } \\
\text { - sytuacja finansowa } \\
\text { - płynność finansowa }\end{array}$ \\
\hline $\begin{array}{l}\text { Konkurencja (inni } \\
\text { świadczeniodawcy) }\end{array}$ & $\begin{array}{l}\text { - } \text { sytuacja majątkowo-finansowa } \\
\text { - wynik finansowy } \\
\text { - koszty świadczeń zdrowotnych } \\
\text { - ceny świadczeń zdrowotnych }\end{array}$ \\
\hline Społeczność lokalna & $\begin{array}{l}\text { - } \text { sytuacja finansowa } \\
\text { - rezultaty działalności }\end{array}$ \\
\hline
\end{tabular}

Źródło: opracowanie własne na podstawie [Hass-Symotiuk (red.) 2010, s. 30-33; 2014, s. 26-31].

Proces restrukturyzacji jako dotyczący jednostek kontynuujących działalność gospodarczą jeśli jest procesem pozasądowym, nie wpływa zasadniczo na tworzenie nowych grup interesariuszy. $Z$ kolei w przypadku sądowych postępowań restrukturyzacyjnych szczególnie ważnymi grupami interesariuszy stają się przedstawiciele sądu, w tym sąd, sędzia-komisarz, nadzorca sądowy, nadzorca układowy lub zarząd$\mathrm{ca}^{1}$ [Bauer 2016].

Jak wskazano w tabelach 1 i 2, wśród poszczególnych grup interesariuszy wewnętrznych i zewnętrznych szpitala informacja o sytuacji finansowej szpitala jest

${ }^{1}$ Powołanie nadzorcy sądowego, układowego lub zarządcy zależne jest od prowadzonego postępowania restrukturyzacyjnego. Nowe Prawo restrukturyzacyjne przewiduje cztery rodzaje postępowań [Ustawa z dnia 15 maja 2015]. 
istotna. Niezależnie od tego, czy restrukturyzacja jest prowadzona w sądzie, czy poza nim, może zmieniać czy nasilać określone potrzeby informacyjne wszystkich grup interesariuszy. Jak wskazuje Wędzki [2015], dla sądu upadłościowego, który również prowadzi postępowania restrukturyzacyjne ${ }^{2}$, potrzebne będą dowody, na podstawie których wyda wyrok. Natomiast interesariusze zewnętrzni, zaangażowani kapitałowo, do których zalicza się wierzycieli, będą zainteresowani informacjami na temat zagrożenia kwoty głównej wierzytelności i ewentualnych odsetek.

Ocenie kondycji finansowej szpitala powinno służyć udostępnione sprawozdanie finansowe.

\section{Wykorzystanie sprawozdania finansowego w praktyce restrukturyzowanych szpitali}

Restrukturyzacja jest procesem nieuniknionym, lecz przewidywalnym. Jedyne, na co można wpływać, to jego przebieg. Korzystnie jest, aby był to wieloetapowy, długofalowy proces, służący jasno określonej strategii, a nie jednorazowy incydent, mający rozwiązać doraźnie pojawiające się problemy. Ponad dwudziestoletnia historia restrukturyzacji szpitali w Polsce wskazuje jednak, że proces ten zachodzi ze zmienną intensywnością. Co 5-10 lat pojawiają się okoliczności wymagające jego przyspieszenia, związane najczęściej z pogarszającą się kondycją finansową tych jednostek [Koziarkiewicz 2011, s. 7].

Proces restrukturyzacji, jak każdej innej jednostki, wymaga przygotowania, które powinno być ujęte w planie. Jednak samo planowanie nie daje gwarancji powodzenia przeprowadzonych działań. Jak stwierdza Kuśmierek [2016, s. 108], ,jest wiele przykładów powierzenia przez organy stanowiące samorządów terytorialnych sporządzenia planów naprawczych zewnętrznym firmom doradczym czy zlecenia restrukturyzacji menedżerom zewnętrznym - i przykłady te potwierdzają brak efektywności tych planów oraz działań restrukturyzacyjnych". Ryzyko niepowodzenia procesu restrukturyzacji szpitala oraz ochrona praw interesariuszy powinna skutkować zwiększaniem przejrzystości informacji dotyczących sytuacji finansowej jednostki.

Z powyższych rozważań wynika, że sprawozdanie finansowe - jako wciąż najlepsza podstawa do oceny kondycji finansowej jednostki - może i powinno dostarczać informacje dla interesariuszy restrukturyzowanych szpitali. W celu określenia praktyki związanej z umożliwieniem wykorzystania sprawozdania finansowego jako źródła informacji w procesach restrukturyzacji szpitali przeprowadzono badania empiryczne.

Jako że jednym z głównych źródeł informacji w analizowanym procesie szpitala jest jego plan restrukturyzacji, badaniami objęto tę część dokumentacji. W bada-

${ }^{2}$ Pomimo rozdzielenia postępowań na odrębne upadłościowe i restrukturyzacyjne, obydwa rodzaje spraw prowadzone są w tych samych wydziałach dla spraw restrukturyzacyjnych i upadłościowych. 
niach uwaga została skupiona na kwestiach związanych z dostępnością sprawozdania finansowego dla interesariuszy restrukturyzowanego szpitala jako podstawy:

1) do dokonania samodzielnej analizy przez zainteresowane strony,

2) przeprowadzonych i udostępnionych analiz finansowych, sporządzonych przez autorów planu restrukturyzacji.

Na metodę badawczą składały się analizy przypadków dostępnych on-line planów restrukturyzacji szpitali. W wyniku przeprowadzonych badań pozyskano cztery plany restrukturyzacji poniżej wymienionych jednostek:

1. Specjalistycznego Szpitala im. E. Szczeklika w Tarnowie, który przechodził proces restrukturyzacji od roku 1999. Analizowany projekt restrukturyzacji odnosi się do kontynuacji prowadzonych działań.

2. Samodzielnego Publicznego Zakładu Opieki Zdrowotnej Szpital nr 2 im. Tadeusza Boczonia w Mysłowicach. Analizowany projekt restrukturyzacji omawia sytuację $\mathrm{w}$ okresie minionych 5 lat oraz plany na kolejne 5 lat.

3. Szpitala Powiatowego w Limanowej, który pomimo dodatniego, jednak zmniejszającego się od 2007 r. wyniku finansowego zdecydował się na przeprowadzenie restrukturyzacji naprawczej. Dodatnie wyniki finansowe są konsekwencją wcześniejszej, zapoczątkowanej w 2006 r. restrukturyzacji.

4. Pomorskiego Centrum Chorób Zakaźnych i Gruźlicy sp. z o.o. Plan restrukturyzacji został sporządzony w związku ze staraniami uzyskania kredytu na spłatę zobowiązań i poprawę płynności finansowej spółki.

Liczebność dostępnych przykładów do badań w przestrzeni internetowej wskazuje na ograniczoną skłonność do dzielenia się ze wszystkimi potencjalnymi interesariuszami informacjami zawartymi w planach restrukturyzacji, ze szczególnym uwzględnieniem sprawozdań finansowych.

W toku dalszych badań przeprowadzono analizę planów restrukturyzacji pod kątem zamieszczenia w nich sprawozdania finansowego oraz odwołań do informacji w nich zawartych w całym dokumencie. Syntetyczne wnioski przedstawiono w tabeli 3.

Jak wynika z przeprowadzonych badań, widoczne jest zróżnicowane podejście do ujawniania sprawozdania finansowego oraz wskaźników finansowych jako podstawy oceny kondycji finansowej szpitala. W pierwszym z badanych przypadków nie ujawniono żadnych informacji pochodzących ze sprawozdania finansowego czy obliczonych na jego podstawie. Nie oznacza to, iż pełny plan restrukturyzacji ich nie zawierał, gdyż dostępna on-line wersja nie jest kompletna. W drugim przypadku zamieszczone sprawozdania finansowe sporządzone są dla okresów przyszłych, natomiast analiza finansowa dotyczy zarówno danych historycznych, jak i planowanych. Również w trzecim przypadku brak udostępnionych sprawozdań finansowych, jednak wyraźnie wskazano, że stanowią one załącznik do planu restrukturyzacji. Wybiórczo, w niejednolity dla różnych okresów sposób zamieszczono wskaźniki finansowe.

Reasumując, analizowane przypadki wskazują na ograniczone udostępnianie w wirtualnej przestrzeni sprawozdania finansowego oraz jego analiz jako źródła informacji dla interesariuszy szpitala przechodzącego proces restrukturyzacji. Nato- 
Tabela 3. Sprawozdania finansowe $i$ ich analiza w planach restrukturyzacji szpitali

\begin{tabular}{|c|c|c|}
\hline Analizowany dokument & Sprawozdanie finansowe & Analiza finansowa \\
\hline $\begin{array}{l}\text { PROJEKT PROGRAMU } \\
\text { RESTRUKTURYZACJI } \\
\text { Specjalistycznego Szpitala } \\
\text { im. E. Szczeklika w Tarnowie na lata 2005-2010 } \\
\text { czerwiec } 2005 \\
\text { Objętość: } 53 \text { strony } \\
\text { Dostępne: } 22 \text { strony }\end{array}$ & $\begin{array}{l}\text { W udostępnionej części: brak jakichkolwiek } \\
\text { elementów sprawozdania finansowego }\end{array}$ & $\begin{array}{l}\text { W udostępnionej czę́si: brak obliczeń jakichkolwiek wskaźników. } \\
\text { Podano informacje na temat udziałów poszczególnych zobowiązań } \\
\text { w zobowiązaniach ogółem }\end{array}$ \\
\hline $\begin{array}{l}\text { PROJEKT PROGRAMU } \\
\text { RESTRUKTURYZACYJNEGO } \\
\text { Samodzielnego Publicznego Zakładu Opieki } \\
\text { Zdrowotnej } \\
\text { Szpital nr } 2 \\
\text { im. dra Tadeusza Boczonia w Mysłowicach } \\
\text { sierpień } 2005 \\
\text { Objętość: } 68 \text { stron } \\
\text { Dostępne: } 68 \text { stron }\end{array}$ & $\begin{array}{l}\text { Zamieszczono bilans, rachunek zysków i strat oraz } \\
\text { rachunek przepływów pieniężnych sporządzone jako } \\
\text { plany finansowe na lata 2005-2010 }\end{array}$ & $\begin{array}{l}\text { Projekt zawiera zarówno wstępną analizę sprawozdania finansowego, jak } \\
\text { i analizę wskaźnikową. Analizy zostały sporządzone w trybie ex post za lata } \\
2000-2004 \text { oraz ex ante dla lat 2005-2010. } \\
\text { We wstępnej analizie w trybie ex post dokonano oceny zmian głównych pozycji } \\
\text { bilansu i rachunku zysków i strat (ze szczególnym uwzględnieniem kosztów } \\
\text { w układzie rodzajowym). } \\
\text { W analizie wskaźnikowej obliczono główne wskaźniki rentowności, płynności, } \\
\text { efektywności zarządzania zasobami i zadłużenia. Dokonano interpretacji zmian } \\
\text { w czasie i podjęto próbę analizy przyczynowej. } \\
\text { Analiza w trybie ex ante składa się z analizy wstępnej i wskaźnikowej } \\
\text { sporządzonej na podstawie planów finansowych na lata 2005-2010. Analiza } \\
\text { finansowa zakłada daleko idące polepszenie wskaźników finansowych } \\
\text { w kolejnych okresach działalności }\end{array}$ \\
\hline $\begin{array}{l}\text { OPRACOWANIE OBSZARÓW } \\
\text { RESTRUKTURYZACYJNYCH } \\
\text { Szpital Powiatowy w Limanowej } \\
\text { grudzień } 2011 \\
\text { Objętość: } 184 \text { strony } \\
\text { Dostępne: } 184 \text { strony }\end{array}$ & $\begin{array}{l}\text { Nie zawiera pełnego sprawozdania finansowego, } \\
\text { ale uproszczoną wersję bilansu i rachunku zysków } \\
\text { i strat za lata 2008-2010 oraz koszty w układzie } \\
\text { rodzajowym za I-IX } 2011 \mathrm{r} \text {. z podziałem na } \\
\text { poszczególne oddziały szpitala. Przedstawiono } \\
\text { również koszty działalności operacyjnej szpitala za } \\
2007 \text { r. Ponadto zamieszczono prognozę rachunku } \\
\text { zysków i strat na rok } 2012 \text { w porównaniu do } 2011 \mathrm{r} \text {. }\end{array}$ & $\begin{array}{l}\text { Zawiera wstępną analizę sprawozdania finansowego oraz analizę wskaźnikową } \\
\text { za lata 2008-2010 }\end{array}$ \\
\hline $\begin{array}{l}\text { PLAN RESTRUKTURYZACJI ZADŁUŻENIA } \\
\text { SPÓŁKI Pomorskie Centrum Chorób Zakaźnych } \\
\text { i Gruźlicy sp. z o.o. } \\
\text { czerwiec } 2013 \\
\text { Objętość: } 56 \text { stron* } \\
\text { Dostępne: } 56 \text { stron* } \\
\text { *bez załączników }\end{array}$ & $\begin{array}{l}\text { W treści dokumentu podano, iż bilans, rachunek } \\
\text { wyników i przepływy pieniężne na lata 2013-2023 } \\
\text { stanowią załączniki do planu restrukturyzacji. Nie są } \\
\text { one jednak integralną częścią, załączoną i dostępną } \\
\text { dla interesariuszy szpitala. } \\
\text { Zaprezentowano symulację uproszczonego bilansu } \\
\text { oraz wybrane pozycje rachunku zysków i strat po } \\
\text { I kwartale } 2013 \text { r. }\end{array}$ & $\begin{array}{l}\text { Podano podstawowe wskaźniki rentowności, płynności i zadłużenia za rok 2011, } \\
\text { wykresy wybranych wskaźników za lata 2005-2011 oraz wybrane wskaźniki po } \\
\text { I kwartale } 2013 \text { r. }\end{array}$ \\
\hline
\end{tabular}

Źródło: opracowanie własne na podstawie planów restrukturyzacji szpitali. 
miast mała liczebność dostępnych planów restrukturyzacji w przestrzeni internetowej podkreśla niechęć do dzielenia się informacją ze wszystkimi potencjalnie zainteresowanymi interesariuszami.

\section{Zakończenie}

Poszukiwanie rozwiązań mających na celu poprawę kondycji finansowej szpitali i zapewnienie możliwości kontynuacji ich działalności sprawiają, że podmioty te przechodzą szereg procesów restrukturyzacyjnych [Chluska 2005, s. 124]. Restrukturyzacja jest procesem trudnym, który powinien obejmować wiele obszarów działalności gospodarczej. Złożoność tego procesu dotyczy tym bardziej specyficznych jednostek, jakimi są szpitale, co podkreślają badania naukowe [np. Fijałkowska 2013; Klich 2013]. Niemniej jednak, pomimo złożoności procesów restrukturyzacji jednostek świadczących usługi w zakresie opieki zdrowotnej, należy mieć na względzie to, iż są to także jednostki prowadzące działalność biznesową i również narażone na - wymagające rozwiązywania - problemy finansowe. Specyfika tego typu działalności wpływa również na niepewność związaną z realizacją długoterminowych planów restrukturyzacji [Kuśmierek 2016].

Interesariusze zadłużonych szpitali mają prawo oczekiwać, iż będą informowani na temat kondycji finansowej restrukturyzowanych podmiotów. Przeprowadzone badania empiryczne wskazują na dość dużą dowolność w zakresie publikowanej on-line informacji finansowej przez restrukturyzowane szpitale. W analizowanych przypadkach można stwierdzić, iż udostępnione plany restrukturyzacji zawierają jedynie wybiórcze informacje pochodzące ze sprawozdań finansowych i ich analizy. Głównym wnioskiem płynącym z badań jest ten, iż restrukturyzowane szpitale generalnie niechętnie udostępniają sprawozdania finansowe w planach restrukturyzacji.

Rok 2016 przyniósł znaczące zmiany w zakresie możliwości przeprowadzania sądowych procesów restrukturyzacyjnych i wynikające stąd kwestie regulacji prawnych w zakresie dostępu do sprawozdania finansowego interesariuszy restrukturyzowanych szpitali. Z uwagi na krótki okres obowiązywania nowego Prawa restrukturyzacyjnego aspekt ten nie został poddany badaniom w niniejszym artykule. Jednak zmiany prawne stanowić będą przyczynek do dalszych badań w temacie informacyjnej roli sprawozdania finansowego restrukturyzowanych szpitali.

\section{Literatura}

Bauer K., 2016, Ujawnienia informacji na temat postępowania restrukturyzacyjnego w sprawozdaniach finansowych spółek notowanych na Giełdzie Papierów Wartościowych w Warszawie, Finanse, Rynki Finansowe, Ubezpieczenia, nr 4(82) (cz. 2 Rynek kapitałowy i wycena przedsiębiorstw), s. 571-580.

Bem A., Prędkiewicz K., Prędkiewicz P., Ucieklak-Jeż P., 2014, Determinants of Hospital's Financial Liquidity, Procedia Economics and Finance, vol. 12, s. 27-36.

Chluska J., 2005, Polityka rachunkowości samodzielnych publicznych zakładów opieki zdrowotnej w procesach restrukturyzacji, Zeszyty Teoretyczne Rachunkowości, t. 28(84), s. 124-133. 
Chluska J., 2010, Rola sprawozdania finansowego w procesach restrukturyzacji samodzielnych publicznych zakładów opieki zdrowotnej, Studia i Prace Uniwersytetu Ekonomicznego w Krakowie, nr 14, t. 1, s. 97-105.

Chluska J., 2014, Rachunkowość podmiotów leczniczych, Wolters Kluwer SA, Warszawa.

Hass-Symotiuk M. (red.), 2008, Rachunkowość i sprawozdawczość zakładów opieki zdrowotnej, ODDK, Gdańsk.

Hass-Symotiuk M. (red.), 2010, Rachunkowość: system informacji finansowych Zakładów Opieki Zdrowotnej, Wolters Kluwer, Warszawa.

Hass-Symotiuk M. (red.), 2014, Zaawansowana rachunkowość finansowa podmiotów leczniczych, Wolters Kluwer, Warszawa.

Klich J., 2013, Restrukturyzacja samodzielnych publicznych zakładów opieki zdrowotnej: współczesne wyzwania, procedury i narzędzia, Wolters Kluwer, Warszawa.

Kołaczyk Z., 1999, Rachunkowość finansowa, Wydawnictwo Akademii Ekonomicznej w Poznaniu, Poznań.

Kozierkiewicz A., 2011, Restrukturyzacja zakładów opieki zdrowotnej w Polsce. Przewodnik przygotowania projektu, Projekt Nowoczesne zarządzanie w zakładach opieki zdrowotnej - szkolenia z zakresu rachunku kosztów i informacji zarządczej oraz narzędzi restrukturyzacji i konsolidacji ZOZ, współfinansowany ze środków Unii Europejskiej w ramach Europejskiego Funduszu Europejskiego, http:// www.nzzoz.mz.gov.pl/uploads/static/02_Restrukturyzacja_zakladow_opieki_zdrowotnej.pdf (dostęp: 23.05.2017).

Kuśmierek P., 2016, Zdolność restrukturyzacyjna samodzielnych publicznych zaktadów opieki zdrowot$n e j$, Doradca Restrukturyzacyjny, nr 5(3/2016), s. 108-116.

Macuda M., 2016, Obszary badań naukowych w rachunkowości jednostek sektora opieki zdrowotnej, [w:] Nowak E., Kowalewski M., Nieplowicz M. (red.), Rachunkowość a controlling, Prace Naukowe Uniwersytetu Ekonomicznego we Wrocławiu, nr 440, s. 401-410.

Opracowanie obszarów restrukturyzacyjnych - Szpital Powiatowy w Limanowej, 2011, Łódź, https:// limanowa.in/pliki/file/opracowanie.pdf (dostęp: 26.05.2017).

Plan restrukturyzacji zadłużenia spółki - Pomorskie Centrum Chorób Zakaźnych i Gruźlicy sp. z o.o., 2013, Gdańsk, http://www.pcchz.pl/pages/siwz/akt/Biznes\%20Plan_Pozyczka_13_mln_PCChZiG \%20(2).pdf (dostęp: 26.05.2017).

Projekt programu restrukturyzacyjnego Samodzielnego Publicznego Zakładu Opieki Zdrowotnej Szpital nr 2 im. dra Tadeusza Boczonia w Mysłowicach, 2005, Mysłowice, http://www.bip.myslowice. $\mathrm{pl} /$ data/dataPublicator/restrukturyzacja_szpital_nr2.doc (dostęp 26.05.2017).

Projekt programu restrukturyzacji Specjalistycznego Szpitala im. E. Szczeklika w Tarnowie na lata 2005 - 2010, 2005, Tarnów, http://bip.malopolska.pl/pobierz/1026895.html (dostęp 26.05.2017).

Sagan A., Sobczak A., 2014, Implementation of the 2011 Therapeutic Activity Act: Will commercialization improve the financial performance of Polish hospitals?, Health policy, vol. 118, issue 2, s. 153-158.

Samelak J., 2013, Zintegrowane sprawozdanie przedsiębiorstwa społecznie odpowiedzialnego, Wydawnictwo Uniwersytetu Ekonomicznego w Poznaniu, Poznań.

Świderska G.K., Pielaszek M., 2015, Rachunkowość zarzadcza w podmiotach leczniczych, Wolters Kluwer SA, Warszawa.

Ustawa z 15 maja 2015 r. - Prawo restrukturyzacyjne, Dz.U. z 2015 r., poz. 978.

Wawrowski R., 2014, Specyfika polityki rachunkowości samodzielnych publicznych zakładów opieki zdrowotnej, Studia Ekonomiczne, nr 201, s. 393-403.

Wędzki D., 2015, Analiza wskaźnikowa sprawozdania finansowego wedtug polskiego prawa bilansowego, Oficyna Wydawnicza Wolters Kluwer business, Warszawa.

Węgrzyn M., 2013, Uwarunkowania systemowe restrukturyzacji publicznych podmiotów leczniczych w Polsce, Monografie i Opracowania Uniwersytetu Ekonomicznego we Wrocławiu, nr 242.

Zaleska B., Wallis A., 2008, Rachunkowość zakładu opieki zdrowotnej, Zeszyty Naukowe Wydziału Nauk Ekonomicznych Politechniki Koszalińskiej, nr 12, s. 213-220.

Zimmerman P., 2016, Prawo restrukturyzacyjne. Komentarz, Legalis, C.H. Beck, Warszawa. 